\title{
Development of a Story Based Auditory Training Tool and Evaluation of the Training Efficacy for Adult Hearing Impaired Listeners
}

\author{
Na Kyung Kim ${ }^{1.2}$, Junghwa Bahng ${ }^{1}$ \\ 'Department of Audiology, Hallym University of Graduate Studies, Seoul, Korea \\ ${ }^{2}$ Keumgang Hearing Aids Center of Ansan, Ansan, Korea
}

\author{
성인 난청인을 위한 이야기를 이용한 청능훈련 도구 개발 및 청능훈련 효과에 관한 연구 \\ 김 나 경,2.방 정 화 \\ 한림국제대학원대학교 청각학과 ${ }^{1}$, 금강보청기 안산센터 ${ }^{2}$
}

\begin{abstract}
Purpose: The purpose of this study was to develop lists of stories for the auditory training and to evaluate the effect of 10-week auditory training using developed stories for hearing-impaired listeners. Methods: A total of fifty-five stories and related subjective and objective questions were developed. In order to validate the training materials, thirty-two participants examined the familiarity of stories, the interest of stories, the difficulty of sentences, the familiarity of words and the difficulty of questions. According to the validation results, the stories were revised and recorded by a professional female speaker. For determining the efficacy of auditory training using developed stories, fifteen hearing-impaired listeners participated. Among them, eight subjects (auditory training group) received the 40-minute, once per a week for 10-week auditory training, and seven control subjects (non-training group) did not receive any auditory training. Sentence recognition scores with and without noise and Korean version of international outcome inventory for hearing aids (K$\mathrm{IOI}-\mathrm{HA}$ ) were evaluated at before and after the auditory training. Non-training group underwent the same battery of tests at the same time intervals equivalent to the training group. Results: Results showed that the auditory training enhanced sentence recognition in quiet as well as in noise conditions. Also, there was positive impacts of training on the results of $\mathrm{K}-\mathrm{IOI}-\mathrm{HA}$. Conclusion: These results suggested that the 10-week auditory training using the stories is useful to improve speech understanding of hearing aid users as well as their subjective satisfaction on hearing aids.
\end{abstract}

Key Words: Auditory training, Hearing impaired listener, Hearing aids.

Received: April 2, 2017 / Revised: April 11, 2017 / Accepted: April 15, 2017

Correspondence: Junghwa Bahng, Department of Audiology, Hallym University of Graduate Studies, 405 Yeoksam-ro, Gangnam-gu, Seoul 06198, Korea Tel: +82-70-8680-6933 / Fax: +82-2-3451-6618 / E-mail: bahng.jh@gmail.com

\section{INTRODUCTION}

세계보건기구(World Health Organization)에서는 난청을 전 세계에서 13번째로 흔한 주요 장애로 추정하고 있다. 또한, 후 천성 난청은 당뇨와 후천성 면역결핍증후군의 발병수를 넘어, 2030년에는 7번째의 주요장애가 될 것이라고 예측하였다 (Mathers et al., 2008). 우리나라 국민건강보험공단의 '전음성 및 감각신경성 난청'의 건강보험 진료비 지급자료를 분석한 결
과에 따르면, 난청으로 인한 진료인원이 2008년 22만 2,000명 에서 2013년 28만 2,000명으로 연평균 4.8\%씩 증가했으며, 전 체 연령대에서 60 대 이상이 $44.5 \%$ 로 가장 많은 비중을 차지했 고, 50대 7.1\%, 40대 $11.5 \%$ 순으로 난청으로 인하여 병원을 찾 는 인구가 노년에만 머무르지 않는 것으로 나타났다(National Health Insurance Corporation, 2014).

보청기가 난청을 중재하는 가장 보편적인 방법임에도 불구하 고 의사소통의 능력이 기대만큼 증대하지 않거나 불편하다는 
이유로 많은 사용자가 보청기 착용을 거부하고 있다. 지난 20 년간의 보청기 기술 발전으로 인하여, 신호대잡음비(signal to noise ratios, SNRs)가 향상되며 보청기의 착용을 통한 의사소 통 능력이 향상되었으며, 보청기 만족도는 과거에 비하여 증가 하고 있는 추세이다(Kochkin, 2010). 그러나 여전히 보청기 착 용 후 소음 상황에서의 단어인지도(word recognition score)와 소리의 방향을 탐지하는 데 어려움이 해결되지 않고 의사소통 의 개선이 미비하며, 소음상황에서 말소리에 대한 탐지, 변별, 확인 및 이해가 어려워 보청기를 착용하지 않는 것으로 나타났 다(Johnson \& Dillon, 2011).

이외에도 음향적 정보 듣기의 어려움은 청각적 기억력의 감 퇴와 의사소통의 어려움으로 연결될 수 있다(Pichora-Fuller \& Singh, 2006; Schneider et al., 2000). 의사소통의 증진은 음 향적 정보를 듣는 것만으로 증가하지 않으며 이를 이해하는 인 지능력이 향상되어야 한다. 따라서, 난청인의 의사소통을 개선 하기 위해서는 보청기의 착용만이 유일한 선택이 될 수 없으며, 난청인 중심의 교육, 상담 그리고 청능훈련을 포함하는 재활치 료적 접근이 동반되어야 한다(Sweetow \& Sabes, 2006).

청능훈련은 보청기를 통하여 들어가는 새로운 소리를 뇌에 익히는 과정으로 집중적인 소리듣기 연습을 통해 소리를 듣는 방법을 익히는 과정(Sweetow \& Sabes, 2006)으로 정의할 수 있다. 이러한 훈련은 보청기에 대한 만족도뿐만 아니라 의사소 통의 향상을 기대할 수 있다(Pichora-Fuller \& Levitt, 2012). 훈련의 방법으로는 음소와 단어 위주의(bottom-up approach) 의 분석적(analytic) 청능훈련과 일상생활 속의 의사소통 방식 과 유사한 문장, 이야기 등을 이용한 하향식 접근 방식(topdown approach)의 종합적(synthetic) 청능훈련으로 나눌 수 있 다. 하향식 접근 방식의 종합적 청능훈련은 음향적인 정보와 함 께 인지적인 활동이 이루어져야 하기 때문에 소리에 대한 집중 력의 증가로 뇌의 듣기활동을 가속화할 수 있으며(Henshaw \& Ferguson, 2013), 의사소통 개선의 효과 또한 기대할 수 있다 (Yeo et al., 2014). 하향식 접근 방식의 종합적 청능훈련은 청자 에게 듣기활동을 통한 청각적 기억력을 요구하여 신경처리속도 의 향상과 함께 소음 하 어음인지 또한 증가하였음을 보였고 (Anderson et al., 2013), 훈련되지 않은 소리에 대한 기억력과 처리속도에서도 일반적인 향상이 있었음을 보고하였다(Smith et al., 2009). 이러한 소리에 대한 집중력과 기억력 증가를 목적 으로 개발된 청각과 인지력의 통합훈련프로그램인 Listening and Communication Enhancement (LACE ${ }^{\circledR}$, Neurotone Inc., Redwood City, CA, USA)의 경우 자가 보고된 의사소통의 어 려움이 개선되었을 뿐 아니라 소음 속 대화, 청각적 작업 기억 (auditory working memory) 그리고 언어 처리의 속도에서 일 반적인 향상이 있음을 입증하였다(Sweetow \& Sabes, 2006).
청능훈련 프로그램인 $\mathrm{LACE}^{\circledR}$ 의 경우 통합적 사고능력을 요구 하는 하향식 접근방식의 훈련은 맞으나, 문장수준으로 개발되어, 좀 더 높은 수준의 기억력을 요구하는 훈련은 가능하지 않다.

본 연구의 목적은 의사소통의 증진을 목적으로 한 한국어 청 능훈련 도구 개발에 있다. 현재 국내에서의 청능훈련 도구는 환 경음(Ahn \& Lee, 2016), 단어(Baek \& Lee, 2016), 문장(Chang $\&$ Lee, 2016), 그리고 두 문장으로 이루어진 이야기까지 개발되 었다(Lim \& Bahng, 2016). 앞의 개발된 한국어로 된 청능훈련 도구 개발의 맥락에서 의사소통 능력 향상을 위하여 소리에 대 한 집중력과 기억력 향상, 그리고 문장 안에서 핵심단서를 잡을 수 있는 전략을 키우는 것을 목적으로 한 이야기를 이용한 청 능훈련 도구를 본 연구에서 개발하고자 하였다. 난이도의 조절 은 신호대잡음비를 조절하도록 하여 일상생활의 의사소통 환 경과 유사한 상황에서의 듣기 능력의 향상을 시키고자 하였다. 또한 연구를 통해 개발된 이야기 청능훈련 도구를 이용하여 10 주간의 소음 하 청능훈련이 어음인지능력과 주관적인 보청 기 만족도를 향상시키는지 확인하고자 하였다.

\section{[EXPERIMENTAL 1]}

\section{MATERIALS AND METHODS}

\section{이야기 청능훈련 도구의 개발}

난청인의 보청기를 착용 후 어음인지능력 향상을 위한 청능 훈련용 이야기의 선정 과정은 다음과 같다.

\section{이야기 목록 수집}

이야기의 난이도는 개인마다 다를 수 있으므로 주제별로 이 야기를 수집하였다. 이야기는 우리나라 성인들이 알 수 있거나 흥미를 느낄 수 있는 주제로 선정하였다. 각 주제당 5 가지의 이 야기를 수집하였으며, 이야기는 네이버 두산백과, 어린이백과, 음식백과, 한국민속대백과사전, 한국민족문화대백과, 유네스코 유산 등을 참고하여 각 이야기당 4 5개의 문장으로 구성하였 다. 이야기를 듣고 흐름을 파악하고, 이해를 확인하기 위한 질문 은 4 개의 문항으로 구성하였다. 이야기는 총 11 가지의 주제로 나 누어지며, 주제별로 5 가지 이야기가 포함되어 있다.

11 가지의 주제(음식, 축제, 전통문화, 스포츠, 속담, 유명 명소, 나라, 세계 유산, 건강, 인물, 기타)로 구성된 총 55 개의 이야기 를 완성하였고 이야기를 듣고 답안지를 기술하는 방식으로 구 성하였다. 답안지 형식은 서술하기, 선택하기, 빈칸 채우기 등 다양하게 구성하였다.

전통문화의 정월대보름을 예로 들면, "강강술래는 전라남도 해안 지역에서 전해져 내려오던 여성들의 대표 민속놀이입니 
다. 강강술래는 우리나라 명절인 설, 대보름, 단오 그리고 추석 날 밤에 열렸는데, 그중에서 달이 밝은 추석날 밤에 가장 큰 강 강술래 판이 벌어졌습니다. 하늘에 커다란 보름달이 보이면 동 네 여인들은 서로 손을 잡고 둥근 원을 만들며 강강술래를 돌 았습니다. 강강술래는 집안에만 머물며 외출이 힘들었던 여인 들이 밤새도록 놀 수 있었던 놀이로, 당시 여인들의 삶을 엿볼 수 있습니다."

1) 무엇에 관한 설명인가요?

2) 이것은 어느 지역으로부터 전해져 내려오나요?

3) 이것이 가장 크게 열리는 날은 언제였나요?

4) 이것은 누구를 위한 놀이였나요?

속담의 '낮말은 새가 듣고 밤말은 쥐가 듣는다를 예로 들면, "낮말은 새가 듣고 밤말은 쥐가 듣는다는 아무도 안 듣는 상 황에서라도 항상 말조심을 해야 한다는 뜻의 속담입니다. 또한, 아무리 비밀리에 한 말이라도 반드시 남의 귀에 들어가게 된다 는 의미로 사용되기도 합니다. 말조심에 대해 비슷한 속담으로 는 '벽에도 귀가 있다', '발 없는 말이 천 리 간다', '살은 쏘고 주 워도 말은 하고 못 줍는다' 등이 있습니다."

1) '낮말은 ( )가 듣고 밤말은 ( )가 듣는다.'에 대한 설명입 니다.

2) 비슷한 속담으로는 '( )에도 귀가 있다.'

3) 비슷한 속담으로는 '( ) 없는 ( )이 ( )리 간다.'

4) 비슷한 속담으로는 '( )은 쏘고 주워도 ( )은 하고 못 줍 는다.'

\section{이야기 목록 타당성 검증}

수집한 51개의 이야기 목록들에 대한 타당성 검증을 위해서 건청 성인 20 50대 32명이 참여하였다(연령범위: 26세 59세, 남 20명, 여 12명). 참가한 모든 피검자는 검사의 목적에 대한 충분한 설명을 듣고 설문에 참가할 것을 동의하였다. 타당성 검 증방법은 수집한 50 개의 이야기 지문과 질문을 읽고 청능훈련 용으로 사용하기에 적절한지에 대한 사전 설문 조사를 실시하 였다. 이야기 및 질문을 구성하는 단어·문장-내용의 난이도, 친숙도, 흥미도 항목에 대한 주관적인 생각을 상-중·하로 평 가하였다.

\section{RESULTS}

\section{이야기 목록 타당성 검증 결과}

설문 결과, 내용의 친숙도, 내용의 흥미도, 단어의 친숙도는 대체적으로 상, 중에 많이 분포하였으며, 문장과 질문의 난이도 는 보통의 정도를 뜻하는 중이 우세하게 나와 이야기 목록이 쉬운 수준의 훈련도구가 아닌 것으로 나타났다.

수집한 51개의 이야기에 대한 설문 평가를 바탕으로 단어와 문장의 난이도를 조절하였으며, 내용의 친숙도와 단어 및 문장 의 난이도 결과를 중점적으로 이야기 수정을 진행하였다. 또한, 인물에 관한 이야기가 추가되었으면 좋겠다는 기타 의견을 수 렴하여 “윤동주, 퇴계 이황, 헬렌켈러, 신사임당” 이야기를 추가 하였고, 추가된 4 개의 이야기는 보청기 착용자 3 명을 대상으로
Figure 1. Questionnaire result for verification of developed auditory training tool.

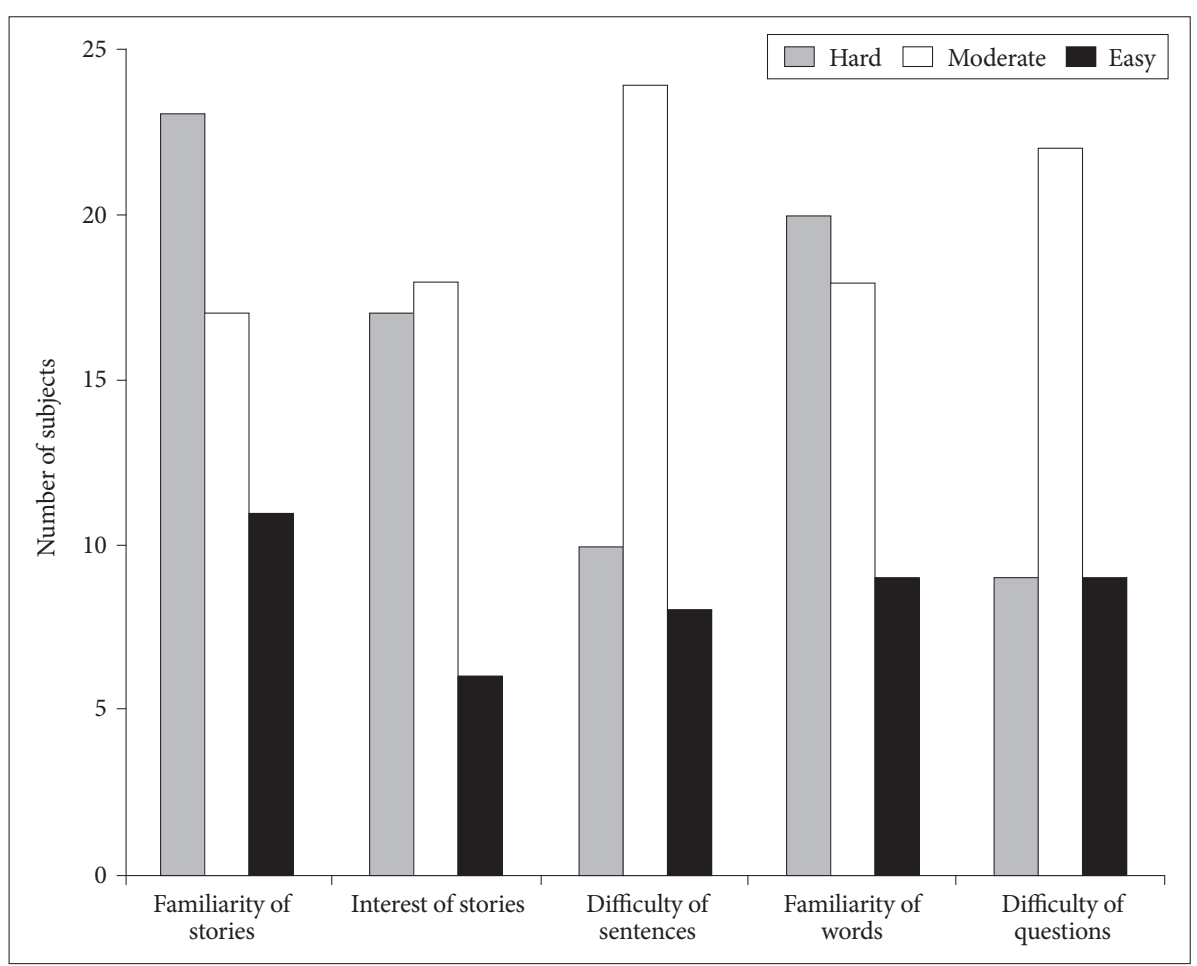


지문의 이해, 질문 검증을 간단히 진행하였다. 이로써 55 개의 이야기에 대한 훈련 적합성을 확인하였다. 51개의 이야기에 대 한 32명의 설문 평가 결과는 Figure 1에 제시하였다.

\section{이야기 목록 음원 제작}

수집한 55 개의 이야기들의 음원 녹음을 위해 한국어 표준말 을 사용하는 성인 여성 1 명이 발화하여 녹음하였다. 녹음을 위 해 AT407 마이크(Audio-technica, Tokyo, Japan), TLM102 (Neuman, Berlin, Germany)를 사용하였다. 녹음된 음원 데이 터는 Adobe Audition version 3.0 (Adobe, San Francisco, CA, USA)를 사용하여 각 음원의 root mean squares (RMS) 강도가 동일하도록 조절하였다. 또한, 소음 하 청능훈련을 위해 Adobe audition 프로그램을 사용하여 각 음원의 RMS는 $25 \mathrm{~dB}$, 앞. 뒤 휴지 간격은 $500 \mathrm{msec}$ 로 조절하고, 소음의 경우 어음형태의 소음(speech-shaped noise)을 0, 3, $6 \mathrm{~dB}$ SNR로 설정하였다.

\section{[EXPERIMENTAL 2]}

\section{MATERIALS AND METHODS}

\section{이야기 청능훈련 효과 검증}

\section{연구 대상}

청능훈련 효과를 확인하기 위해 보청기를 착용하고 있는 난
청인 총 15 명을 대상으로 하였다. 15 명 중 8 명은 청능 훈련그룹 (auditory training group, ATG)으로 참여하였고(남 6, 여 2), 7명 은 청능훈련을 받지 않는 비훈련그룹(non-training group, NTG, 여 5, 남 2)으로 참여하였다. 훈련그룹, 비훈련그룹 대상자 15명 의 연령. 성별, 보청기 착용기간 및 하루 사용시간, 보청기 착용 귀 등에 대한 정보는 Table 1에 제시하였다. 훈련그룹 대상자의 평균 나이는 44.5세(범위: 24 59세, 표준편차: 11.31), 비훈련그 룹의 평균 나이는 59.1세(범위: 31 81세, 표준편차: 19.63)였다. 훈련그룹이 하루에 보청기를 착용하는 시간은 평균 10시간(표 준편차: 3.16)이었고, 비훈련그룹의 하루 보청기 사용시간은 평 균 6.9시간(표준편차: 2.36)이었다.

\section{청능훈련 전후 평가}

청능훈련의 효과를 평가하기 위해 방음부스에서 훈련그룹, 비훈련그룹을 대상으로 문장인지도검사(sentence recognition score)를 실시하였다. 훈련그룹, 비훈련그룹 모두 조용한 환경에 서의 문장인지도와 $0,3,6 \mathrm{~dB} \mathrm{SNR}$ 소음 하에서의 문장인지도 검사를 위해 Korean Standard Sentence Lists for Adults (KS-SL-A) (Jang et al., 2008)를 검사도구로 사용하였다. 청능 훈련의 주관적인 만족도 평가를 하기 위해 설문지 평가를 실시 하였으며, Korean version of International Outcome Inventory for Hearing Aids (K-IOI-HA) (Lee et al., 2005)를 훈련 전후 에 비교하였다(Table 2).

청능훈련 효과를 평가하기 위해 청력검사기(GSI 61; Grason-

Table 1. Demographic information of ATG and NTG subjects

\begin{tabular}{|c|c|c|c|c|c|}
\hline Subjects & Age (years) & Gender & HA experience (months) & Daily use of HA (hours) & HA fitting ear \\
\hline \multicolumn{6}{|l|}{ ATG } \\
\hline 1 & 52 & M & 24 & 12 & Both \\
\hline 2 & 38 & $\mathrm{~F}$ & 4 & 8 & Both \\
\hline 3 & 46 & $\mathrm{~F}$ & 168 & 14 & Both \\
\hline 4 & 41 & M & 108 & 9 & Both \\
\hline 5 & 40 & M & 96 & 12 & Both \\
\hline 6 & 56 & M & 60 & 13 & Both \\
\hline 7 & 59 & M & 120 & 6 & Both \\
\hline 8 & 24 & M & 4 & 6 & Both \\
\hline Mean & 44.5 & & 73 & 10 & \\
\hline \multicolumn{6}{|l|}{ NTG } \\
\hline 1 & 31 & M & 62 & 10 & Both \\
\hline 2 & 69 & $\mathrm{~F}$ & 24 & 4 & Both \\
\hline 3 & 39 & $\mathrm{~F}$ & 36 & 6 & Both \\
\hline 4 & 48 & $\mathrm{~F}$ & 12 & 6 & Both \\
\hline 5 & 77 & $\mathrm{~F}$ & 24 & 8 & Both \\
\hline 6 & 69 & $\mathrm{~F}$ & 18 & 10 & Both \\
\hline 7 & 81 & M & 6 & 4 & Both \\
\hline Mean & 59.1 & & 26 & 6.9 & \\
\hline
\end{tabular}

ATG: auditory training group, NTG: non-training group, HA: hearing aids 
Table 2. Evaluation schedule to evaluate efficacy of auditory training

\begin{tabular}{cccc}
\hline & \multicolumn{1}{c}{$\begin{array}{c}\text { Evaluation at 0 week } \\
\text { (baseline evaluation before training) }\end{array}$} & Training & $\begin{array}{c}\text { Evaluation at 10 week } \\
\text { (immediately after 10-week training) }\end{array}$ \\
\hline ATG & SRS (quiet, 0, 3, 6 dB SNR) & 10-week training & Same protocol at 0 week \\
& K-IOI-HA & No training & Same protocol at 0 week \\
\hline
\end{tabular}

ATG: auditory training group, NTG: non-training group, SRS: sentence recognition score, SNR: signal to noise ratio, K-IOI-HA: Korean version of international outcome inventory for hearing aids

Stadler, Eden Prairie, MN, USA), TDH-50P 헤드폰(Telephonics, Farmingdale, NY, USA), 스피커를 사용하였다. 훈련그룹 의 경우 평가는 총 2회, 훈련 시작 전인 0 주, 10 주 훈련이 끝난 직후인 10 주에 동일하게 시행하였다. 비훈련그룹의 경우 훈련 은 받지 않았으며 0주, 10 주에 걸쳐 훈련그룹과 동일한 검사를 2회 실시하였다.

\section{청능훈련 절차}

한림국제대학원대학교 생명윤리위원회 심의(IRB \#AUD4391 75)에 따라 두 그룹의 피검자는 검사 및 훈련에 대한 설명을 충 분히 들은 후 참가 동의서에 서약하였다. 훈련 중간에 언제든 원 할 경우 훈련을 중단할 수 있으며, 훈련을 완수할 경우 훈련그룹 과 비훈련그룹 각각 소정의 사례비를 지급하였다.

청능훈련은 개발된 이야기 청능훈련 도구를 사용하였으며, 이야기를 듣고 문제를 해결하는 형식의 주관식형 청능훈련을 시행하였다. 주 1 회씩 대략 40 분의 청능훈련을 10 주간 시행하 였다. 청능훈련은 소음 수준이 $50 \mathrm{dBA}$ 이하인 빈 강의실과 같 이 조용한 환경의 공간에서 진행하였다. 훈련 강도 수준은 난청 인 각각의 쾌적레벨(most comfortable level)에서 스피커가 내 장된 노트북(LG15N54; LG, Seoul, Korea)을 사용하여 제시 하였다. 녹음된 이야기를 듣고 문제지에 제시된 4개의 주관식 문제를 통해 이야기 속 핵심 단어를 찾는 하향식 접근 방식의 청능훈련을 진행하였다.

훈련의 난이도는 난청인의 능력에 따라 조절하였다. 소음은 어음형태 소음을 이용하여 $0,3,6 \mathrm{~dB} \mathrm{SNR}$ 상황에서 훈련하였 으며, SNR 강도는 정답률에 따라 다르게 제시하였다. 대상자가 $80 \%$ 의 정답률을 보이는 SNR에서 훈련을 시작하여 $0,3,6 \mathrm{~dB}$ $\mathrm{SNR}$ 로 순서대로 제시하였으며, $6 \mathrm{~dB} \mathrm{SNR}$ 에서도 핵심키워드 를 찾지 못하는 경우에는 조용한 상황에서 제시하였다. 조용한 상황에서 듣게 된 키워드는 처음 제시한 SNR 강도에서 다시 들려주어 소음 하에서 인지가 되는지 확인하였다. 총 55 가지의 이야기 지문을 사용하였으며, 1 회 훈련당 5 6개의 이야기를 이 용하여 훈련을 진행하였다.

청능훈련의 효과를 주관적으로 측정하기 위하여 설문조사 로는 Lee et al.(2005)이 발표한 K-IOI-HA를 사용하였다. K$\mathrm{IOI}-\mathrm{HA}$ 는 신뢰성 평가와 보청기 착용후의 청능훈련 결과를
평가하여 사용자의 주관적 만족도를 확인하는 설문조사이며, 설문지는 총 7 개의 문항(하루 평균 사용시간, 도움의 정도, 사 용 후 개선 정도, 보청기 사용의 가치, 보청기 사용 후 불편 정 도, 타인에게 미치는 부정적 상황, 삶의 질 개선 정도)으로 이루 어져 있다. 문항당 최소 1점에서 최대 5점을 부여할 수 있으며, 총 점수는 최소 5점에서 최대 35점이다.

\section{통계분석}

본 연구결과의 자료분석은 SPSS (PASW Statistics 18, IBM, Armonk, NY, USA)를 사용하여 분석하였다. 그룹(훈련그룹, 비 훈련그룹)은 그룹 간 독립변수로, 평가 시기(0주, 10 주)와 듣기 조건(조용한 상황, $0,3,6 \mathrm{~dB} \mathrm{SNR})$ 을 그룹 내 독립변수로, 소 음 하 문장인지도를 종속변수로 하여 반복 측정 삼원분산분석 (three way mixed ANOVA with 2 within-subject factors and 1 between-subject factor)을 실시하였다. 훈련그룹과 비훈련그 룹의 훈련 전후 K-IOI-HA 설문조사 결과를 비교하기 위하여 훈련 전후를 독립변수로, $\mathrm{K}-\mathrm{IOI}-\mathrm{HA}$ 점수를 종속변수로 하여 비모수 통계분석(Wilcoxon signed rank test)을 실시하였다. 비 모수 통계 결과에서는 중위수(50th)를 비교하였으며, Z값을 보 고하였고, $p<0.05$ 를 기준으로 유의성을 확인하였다.

\section{RESULTS}

훈련효과를 평가하기 위해 0 주, 10 주에 훈련그룹과 비훈련그 룹을 대상으로 조용한 상황, $0,3,6 \mathrm{~dB}$ SNR에서 시행한 소음 하 문장인지도와 설문 평가를 실시하였다. 설문 평가로는 $\mathrm{K}-$ IOI-HA 설문지를 0주와 10주에 각각 평가하였다.

\section{객관적 훈련 효과 평가: 훈련 전후 소음 하 문장인지도 평가}

훈련그룹을 대상으로 0 주에 평가한 조용한 상황, $0,3,6 \mathrm{~dB}$ $\mathrm{SNR}$ 에서의 소음 하 문장인지도 검사 결과 $89.06 \%$ (표준편차: 9.3), 60.94\%(표준편차: 17.6), 45.94\%(표준편차: 23.6), $30.94 \%$ (표준편차: 16.9)였다. 10주에 동일한 조건에서 검사한 결 과 95.31\%(표준편차: 7.0), 72.81\%(표준편차 17.9), 61.56\%(표준편 차: 29.5), 41.56\%(표준편차: 23.5)였다(Figure 2A).

비훈련그룹을 대상으로 0 주에 평가한 조용한 상황, $0,3,6$ 

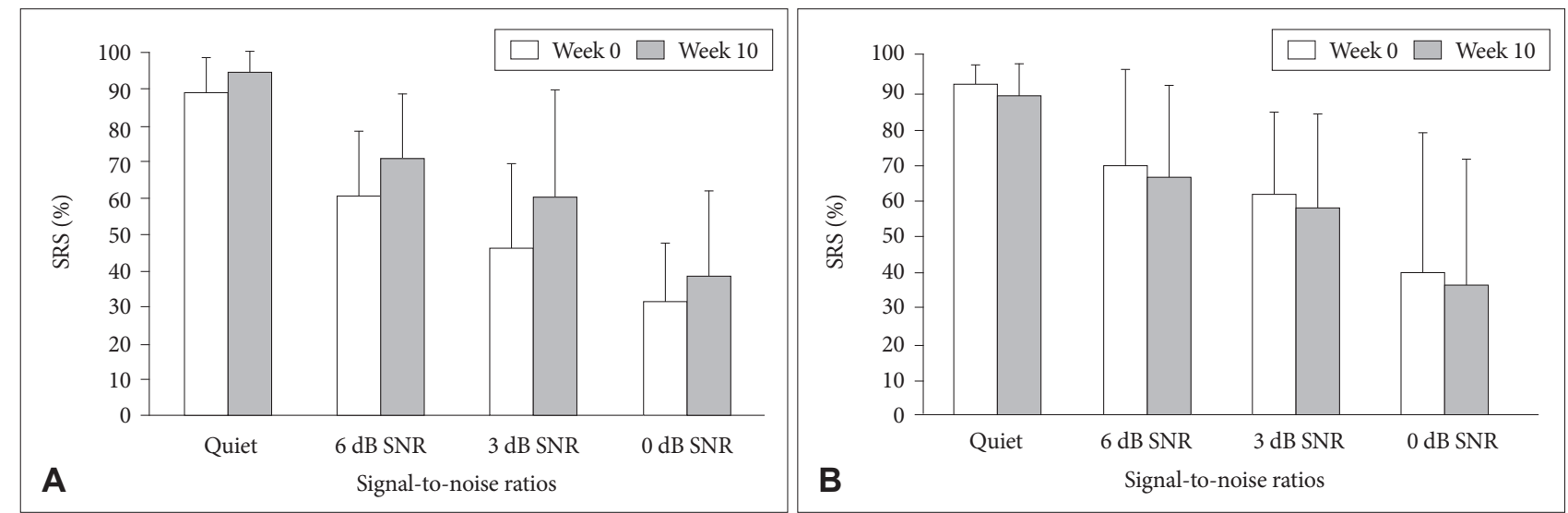

Figure 2. Sentence recognition score (\%) in quiet, $6,3,0 \mathrm{~dB}$ SNR condition for ATG (A) and NTG (B) at 0-week (white bar) and 10-week (gray bar); there was significant difference at all conditions in ATG (A). SRS: sentence recognition scores, SNR: signal to noise ratio, ATG: auditory training group, NTG: non-training group.

$\mathrm{dB}$ SNR에서의 소음 하 문장인지도 검사 결과 $92.14 \%$ (표준편 차: 5.3), 68.93\%(표준편차: 26.5), 60.71\%(표준편차: 23.6), 39.64\%(표준편차: 39.3 )였다. 10주에 동일한 조건에서 검사한 결과 88.57\%(표준편차: 8.9), 66.43\%(표준편차: 25.3), 57.5\%(표 준편차: 25.7), 35.71\%(표준편차: 35.4)였다(Figure 2B).

훈련 전후(0주, 10 주)와 그룹 간 소음 하 문장인지도가 유의 하게 달랐는지 반복 측정 삼원분산분석(repeated measurement of three way ANOVA)을 시행한 결과 훈련 전후에 따라 문장인지도가 유의하게 달랐으며 $[\mathrm{F}(1,13)=17.26, p<0.05]$ 그룹의 주 효과는 유의한 차이가 없었다 $[\mathrm{F}(1,13)=0.02, p>$ 0.05]. 문장인지도 검사 조건(조용한 상황, $6,3,0 \mathrm{~dB} \mathrm{SNR})$ 에 따라서는 유의한 차이가 있었다 $[\mathrm{F}(1.76,22.85)=55.11, p<$ 0.05]. 훈련 전후와 그룹 간 상호작용을 비교한 결과, 훈련그룹 의 경우 훈련 전보다 훈련 후에 문장인지도가 $56.72 \%$ (표준편 차: 6.9)에서 $67.81 \%$ (표준편차: 7.3)로 향상되었으며, 비훈련그룹 의 경우 훈련 전 $65.36 \%$ (표준편차: 7.4$)$ 에서 $62.05 \%$ (표준편차: 7.8)로 유사한 결과가 나왔다. 따라서, 훈련 전후와 그룹 간 상 호작용은 유의하며 $[\mathrm{F}(1,13)=58.94, p<0.05]$, 훈련그룹의 소 음 하 문장인지도가 훈련 후 유의하게 향상하였고 비훈련그룹 의 소음 하 문장인지도는 유의하게 변화하지 않았음을 확인하 였다.

\section{주관적 훈련 효과 평가: $\mathrm{K}-\mid \mathrm{OO}-\mathrm{HA}$ 결과 비교}

훈련그룹과 비훈련그룹의 훈련 전후 $\mathrm{K}-\mathrm{IOI}-\mathrm{HA}$ 설문조사 결 과를 비교하기 위하여 비모수 통계분석(Wilcoxon signed rank test)을 각각 실시한 결과, 훈련그룹은 훈련 전후에 통계적으로 유의한 차이가 있었으나, 비훈련그룹은 유의한 차이가 없었다. 0주 평가에 실시한 훈련그룹의 K-IOI-HA 평균값은 26점(표준 편차: 2.4)이 나왔으며, 10 주 평가에 실시한 결과 27.63점(표준 편차: 3.4)으로 증가하였다. 훈련그룹의 K-IOI-HA의 중위수

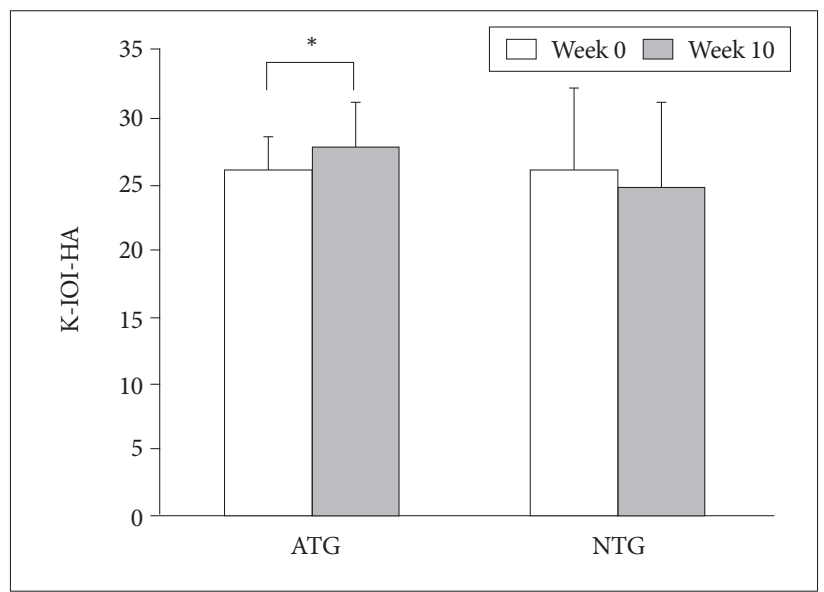

Figure 3. K-IOI-HA for ATG and NTG at 0-week (white bar) and 10week (gray bar), bar means SD. ${ }^{*} p<0.05$. SD: standard deviation. $\mathrm{K}-\mathrm{IOI}-\mathrm{HA}$ : Korean version of international outcome inventory for hearing aids, ATG: auditory training group, NTG: non-training group.

(50th)를 비교하면 0주 평가에서는 2.56점, 10주에 평가에서는 28.5점으로 증가하였다. Z값은 -1.983 이며, $p$ 값은 0.047 로 유의 하게 증가하였다. 반면, 0 주 평가에 실시한 비훈련그룹의 $\mathrm{K}-$ IOI-HA 평균값은 26점(표준편차: 6.2)이었으며, 10주 평가에 실시한 결과 24.57점(표준편차: 6.4)으로 감소하였다. 비훈련그 룹의 K-IOI-HA의 중위수(50th)를 비교하면 0주 평가에서는 25점, 10 주 평가에서는 22점으로 감소하였다. Z값은 -1.289 , $p$ 값은0.197로 유의하게 감소하지 않았다(Figure 3).

\section{DISCUSSIONS}

본 연구의 목적은 기존 환경음, 단어, 문장, 이야기 수준의 청 능훈련 도구 개발과 맥락을 이어, 4 5문장으로 구성된 이야기 와 질문으로 이루어진 훈련도구를 개발하고자 하였으며, 개발 된 도구를 이용하여 청능훈련 효과를 확인하고자 하였다. 
청능훈련 효과 검증은 보청기 착용자를 대상으로 10 주간 청 능훈련을 시행하였으며, 소음 하 청능훈련을 위해 개발하고 녹 음된 음원에 어음형태소음을 $0,3,6 \mathrm{~dB}$ SNR로 삽입하였다. 훈 련의 난이도는 개개인의 능력에 따라 조절하여 $80 \%$ 이상의 정 답률을 보일 경우, 소음이 좀 더 큰 단계로 진입하여 난이도를 상향 조절하였다. 소음이 없음에도 난청인이 계속적으로 오답 을 보일 경우 지문을 보여주며 스스로 잘못 들었던 부분을 확 인하고 다시 반복적으로 듣는 과정을 진행하였다.

훈련 전후 평가에서 소음 하 문장인지의 능력은 유의하게 증 가한 것으로 나타났다. 다양한 배경 소음 속에서의 의사소통은 건청인에게도 어려움을 주며, 난청인들에게는 높은 어음인지력 을 요구한다. Burk \& Humes(2008)는 음향학적 소음 대 잡음 비 향상을 위한 방향성 마이크, 소음 감소 알고리즘 등의 개발 이 꾸준히 이루어지고 있으나 기계적인 도움 외에 중요한 것은 청능훈련을 통한 청자의 인지능력의 향상이라는 점을 강조하 고 있다. 소음 하 청능훈련 연구로, Kwon(2014)은 8주간의 청 능훈련이 소음 하 어음인지력과 사용하는 보청기의 주관적인 만족도 향상에 영향을 주는 것으로 보고하였다. 또한, 6주 동 안 소음 하에서 문장을 사용해 청능훈련을 실시한 결과, 소음 하 문장인지도와 보청기 사용에 대한 만족도가 유의하게 향상 되었다고 밝혔다(Yeo et al., 2014). 이외에도, 다양한 청능훈련 자극음(문장, 자음, 환경음)을 이용한 8주간의 소음 하 청능훈 련이 인지도와 주관적인 만족도 향상에 도움을 주는 연구 (Lee, 2016)도 있었다. 훈련에 사용한 자극음의 종류는 달랐지 만 본 연구와 비슷하게 모두 소음 하 문장인지가 늘어났다는 점은 선행 연구의 결과를 본 연구의 결과가 뒷받침하였다.

청능훈련의 주관적 만족도 향상을 평가하기 위해 K-IOI$\mathrm{HA}$ 설문지를 이용하였다. K-IOI-HA 설문 결과, 훈련그룹의 경우 훈련 전후에 점수가 증가하였으며, 통계적으로 유의한 차 이가 있었다. 비훈련그룹의 경우 훈련 전후에 점수가 감소하였 지만, 통계적으로 유의한 차이가 없었다. 따라서, 훈련에 참여 한 훈련그룹의 K-IOI-HA 점수만 유의하게 증가하였으며, 이 를 통해 주관적인 만족도가 증가했음을 확인하였다. 그러나 본 연구에 참여한 두 그룹의 나이와 보청기 착용시간 등이 달라 영향을 끼칠 수도 있음을 고려할 때 추후 연구에서는 이 점을 보완해야 할 것이다.

10 주간의 청능훈련 후 자체적으로 실시한 인터뷰에서는 훈 련 참가자 모두 지난 10 주간의 청능훈련이 일상생활에서 도움 이 되었다고 답하였으며, 소음 하 청능훈련의 필요성에 대해서 반드시 필요하다는 대답을 하였다. 청능훈련을 위한 51 개의 이 야기 검증단계에서 대다수의 설문참여자들이 $4 \sim 5$ 문장으로 이 루어진 이야기는 난청인의 청능훈련 도구로 사용하기에는 난이 도가 높다는 의견들을 제시했다. 하지만, 실제적으로 훈련에 참
여한 훈련그룹 중에는 조금 더 어려운 훈련 도구를 원하는 경 우도 있었다. 이는 난이도가 다양한 훈련도구를 개발할 필요성 을 제시한다.

청능훈련을 하는 목적은 단순히 어음인지 등의 점수를 향상 시키기 위한 것이 아니라, 일상생활 속에서 타인과의 의사소통 을 향상시키고 난청으로 인한 생활 속의 어려움을 감소시켜 삶 의 질을 향상시키기 위함이다. 현대사회가 고령화 사회로 진입 하고 있는 시점에서, 난청으로 인한 고용, 우울증, 사회적 고립 그리고 삶의 질 저하 등의 어려움(Davis et al., 2007)이 대두됨 에 따라 보청기 착용 인구가 증가하고 있으며, 청능훈련에 대한 관심도 높아지고 있다. 최근 국내에도 문장을 이용한 청능훈련 도구개발(Chang \& Lee, 2016), 환경음을 이용한 청능훈련 도 구개발(Ahn \& Lee, 2016), 가로세로 단어판을 이용한 청능훈 련 도구개발(Baek \& Lee, 2016) 그리고 이야기를 이용한 청능 훈련 도구개발(Lim \& Bahng, 2016) 등 여러 가지 청능훈련에 사용할 수 있는 도구들이 개발되었다. 앞으로 접근성이 용이하 고, 흥미롭고 다양한 난이도의 청능훈련 도구들이 지속적으로 개발된다면, 난청인의 청능훈련 참여 의지를 높일 수 있을 것이 다. 마지막으로, 외국의 $\mathrm{LACE}^{\circledR}$ 프로그램과 같이 컴퓨터화된 청능훈련 프로그램의 개발을 통해 시간과 공간의 제약 없이 자 유롭게 청능훈련에 참여할 수 있다면, 바쁜 현대인들 뿐만 아 니라 거동이 불편한 노인들도 쉽게 청능훈련에 접근할 수 있을 것이다.

중심 단어 : 청능훈련·난청인·보청기.

\section{Acknowledgments}

이 논문은 2015년 대한민국 교육부와 한국연구재단의 지원을 받 아 수행된 연구임(NRF-2015S1A5A8014708). 본 연구에 참여해 주신 난청인분들께 감사드립니다.

\section{REFERENCES}

Ahn, P. \& Lee, K. (2016). Development of environmental sounds for auditory training. Audiology and Speech Research, 12(2), 82-88.

Anderson, S., White-Schwoch, T., Choi, H. J., \& Kraus, N. (2013). Training changes processing of speech cues in older adults with hearing loss. Frontiers in Systems Neuroscience, 7, 97.

Baek, S. S. \& Lee, J. H. (2016). Development of crossword puzzles for auditory training. Audiology and Speech Research, 12(2), 103-108.

Burk, M. H. \& Humes, L. E. (2008). Effects of long-term training on aided speech-recognition perfromance in noise in older adults. Journal of Speech, Language, and Hearing Research, 51(3), 759-771.

Chang, S. \& Lee, J. (2016). Development of auditory training tool for adults using sentences. Audiology and Speech Research, 12(2), 89-96.

Davis, A., Smith, P., Ferguson, M., Stephens, D., \& Gianopoulos, I. (2007). Acceptability, benefit and costs of early screening for hearing disability: A study of potential screening tests and models. Health Technology Assessment, 11(42), 1-294.

Gatehouse, S. \& Noble, W. (2004). The speech, spatial and qualities of hearing scale (SSQ). International Journal of Audiology, 43(2), 85-99.

Henshaw, H. \& Ferguson, M. A. (2013). Efficacy of individual computer- 
based auditory training for people with hearing loss: A systematic review of the evidence. PloS One, 8(5), e62836.

Jang, H., Lee, J., Lim, D., Lee K., Jeon, A., \& Jung, E. (2008). Development of Korean standard sentence lists for sentence recognition tests. $A u-$ diology, 4(2), 161-177.

Johnson, E. E. \& Dillon, H. (2011). A comparison of gain for adults from generic hearing aid prescriptive methods: Impacts on predicted loudness, frequency bandwidth, and speech intelligibility. Journal of the American Academy of Audiology, 22(7), 441-459.

Kochkin, S. (2010). MarkeTrak VIII: Consumer satisfaction with hearing aids is slowly increasing. The Hearing Journal, 63(1), 19-20.

Kwon, Y. J. (2014). Effects of 8-week auditory training: Compressed speech and speech in noise (unpublished master's thesis). Hallym University of Graduate Studies, Seoul.

Lee, J. H., Lee, S. G., \& Bahng, J. (2016). Case study of auditory training for long-term users of hearing aids with poor word recognition. Audiology and Speech Research, 12(3), 190-194.

Lee, M. A., Kim, J. S., \& Ahn, J. H. (2005). International outcome inventory for hearing aids (IOI-HA): Korean version. Korean Journal of Audiology, 9(1), 65-76.

Lim, E. H. \& Bahng, J. (2016). Preliminary study for development of auditory training tool using story and question. Audiology and Speech Research, 12(2), 109-114.

Mathers, C., Fat, D. M., Boerma, J. T., \& World Health Organization.
(2008). The Global Burden of Disease: 2004 Update. Geneva: World Health Organization.

National Health Insurance Corporation. (2014). 45\% of patients aged 60 years old visited hospitals due to hearing loss. Retrieved from http:// www.nhis.or.kr/bbs7/boards/B0039/3140.

Pichora-Fuller, M. K. \& Levitt, H. (2012). Speech comprehension training and auditory and cognitive processing in older adults. American Journal of Audiology, 21(2), 351-357.

Pichora-Fuller, M. K. \& Singh, G. (2006). Effects of age on auditory and cognitive processing: Implications for hearing aid fitting and audiologic rehabilitation. Trends in Amplification, 10(1), 29-59.

Schneider, B. A., Daneman, M., Murphy, D. R., \& See, S. K. (2000). Listening to discourse in distracting settings: The effects of aging. Psychology and Aging, 15(1), 110-125.

Smith, G. E., Housen, P., Yaffe, K., Ruff, R., Kennison, R. F., Mahncke, H. W., et al. (2009). A cognitive training program based on principles of brain plasticity: Results from the improvement in memory with plasticity-based adaptive cognitive training (IMPACT) Study. Journal of the American Geriatrics Society, 57(4), 594-603.

Sweetow, R. W. \& Sabes, J. H. (2006). The need for and development of an adaptive listening and communication enhancement $\left(\mathrm{LACE}^{\mathrm{TM}}\right)$ program. Journal of the American Academy of Audiology, 17(8), 538-558.

Yeo, S., Bahng, J., \& Lee, J. H. (2014). Efficacy of auditory training using sentences in noise for hearing aid users. Audiology, 10(1), 65-75. 